\title{
A bumblefoot outbreak and fatal septicemia in captive aquatic birds in Brazil
}

\author{
Surto de esparavão e septicemia fatal em aves aquáticas cativas no Brasil
}

\author{
Marcus Vinícius Romero Marques ${ }^{\mathrm{I}}$ José Sérgio de Resende ${ }^{\mathrm{I}}$ Rogério Venâncio DonattiI $^{\mathrm{II}}$ \\ Daniel Ambrózio da Rocha Vilela ${ }^{\mathrm{III}}$ Roselene Ecco $^{\mathrm{I}}$ Nelson Rodrigo da Silva Martins ${ }^{{ }^{*}}$
}

\section{- NOTE -}

\section{ABSTRACT}

A bumblefoot outbreak with different prognosis according to host species was studied in captive aquatic avian species. Six wood ducks (Aix sponsa), three scarlet-ibis (Eudocimus ruber), two black-swans (Cygnus atratus), five white-faced ducks (Dendrocygna viduata) and two roseate spoonbills (Platalea ajaja) were kept in a common pen with abrasive pavement pond margin, predisposing to podal skin wear. Incoordination and mortality occurred in the two roseate spoonbils and one black swan. Coagulase-positive penicillinresistant Staphylococcus aureus was isolated from the synovial fluid and from the liver. All birds sharing the pen presented active or cicatricial foot lesions, indicating a possible challenge to the environmental Staphylococci. However, except for the roseate spoonbill and the black swan, which had fatal disease, for all other species the case did not evolve to a clinically debilitating or fatal disease. The different susceptibility to a fatal Staphylococcus aureus coagulase positive infection is discussed.

Key words: aquatic birds, Bumblefoot, pododermatitis, wood duck (Aix sponsa), scarlet-ibis (Eudocimus ruber), black-swan (Cygnus atratus), white-faced duck (Dendrocygna viduata), roseate spoonbill (Platalea ajaja).

\section{RESUMO}

Este trabalho relata um surto de esparavão em aves aquáticas cativas com prognóstico variado conforme a espécie de ave. Foram examinados um marreco carolina (Aix sponsa), três guarás (íbis vermelha) (Eudocimus ruber), dois cisnes negros (Cygnus atratus), cinco marrecas piadeiras (Dendrocygna viduata) e dois colhereiros (Platalea ajaja) mantidos em recinto comunitário, em cativeiro e em criatório. No recinto, a piscina é margeada por borda de cimento abrasivo que possibilita a abrasão da pele podal. Todas as aves apresentaram erosões da pele na face de apoio dos pés, indicando fator predisponente (erosão) similar e possível semelhante desafio infeccioso. Entretanto, incoordenação e mortalidade ocorreram em colhereiros e no cisne negro, mas não nas outras espécies. Staphylococcus aureus coagulase positivo e resistente à penicilina foi isolado do líquido sinovial e do fígado das aves recém-mortas e conservadas em geladeira. A susceptibilidade diferenciada das espécies aquáticas estudadas à infecção por $\boldsymbol{S}$. aureus coagulase positivo é discutida.

Palavras-chave: aves aquáticas, esparavão, marreco carolina (Aix sponsa), guará ou íbis vermelha (Eudocimus ruber), cisne negro (Cygnus atratus), marreca piadeira (Dendrocygna viduata), colhereiro (Platalea ajaja).

An outbreak of bumblefoot was diagnosed in six wood ducks (Aix sponsa), three scarlet-ibis (Eudocimus ruber), two black-swans (Cygnus atratus), five white-faced ducks (Dendrocygna

'Universidade Federal de Minas Gerais (UFMG), Escola de Veterinária. Av. Antônio Carlos, nº 6627, Campus Pampulha, 31270010, Belo Horizonte, MG, Brasil. E-mail: rodrigo@vet.ufmg.br. *Autor para correspondência.

IVale Verde Alambique e Parque Ecológico, Betim, MG, Brasil.

IIIInstituto Brasileiro de Ambiente e Recursos Naturais Renováveis (IBAMA), Centro de Triagem de Animais Silvestres (CETAS), Belo Horizonte, MG, Brasil. 
viduata) and two roseate spoonbills (Platalea ajaja) maintained in a commercial aviary. The bumblefoot or pododermatitis is an infectious and inflammatory lesion of the foot pad and toes of domestic and wild birds, described in Anseriformes, Ciconiiformes, Falconiformes, Galliformes, Passeriformes and Strigiformes (ANDREASEN, 2003; DAVIDSON et al., 1985). The condition may evolve to arthritis, osteomyelitis and septicemia (COOPER \& NEEDHAM, 1976). The roseate spoonbill, the most severely affected species in this case (100\% mortality), is an aquatic bird of order Ciconiiformes with long spoon-shaped bill that occurs from the Southern North, Central and South America, and in Brazil, principally in the CentralWestern region (CORNELL, 2008).

All birds were raised in an hexagonal unpaved partly lawn collective pen $\left(36 \mathrm{~m}^{2}\right)$ having a center pond with cement-paved margin. Incoordination for flight and locomotion were clinically observed. Although all individuals presented active or cicatricial foot lesions, mortality occurred only in the two roseate spoonbills and one black swan. The bacteriological diagnosis was made on samples obtained from the podal lesions and from the liver of one dead spoonbill. An affected roseate spoonbill which died was examined at necropsy and samples for bacteriology (BHI and blood agar, microaerophilic, $37^{\circ} \mathrm{C}$ ) of liver and synovial fluid (tibiotarsal-metatarsal joint) were collected. For histopathology, fragments of liver and kidney were fixed in $10 \%$ buffered formalin. Isolates were described according to colony shape, biochemical (catalase and coagulase) and tinctorial properties (Gram) and for antibiotic sensitivity.

Prior to death, the roseate spoonbills presented severe incoordination and frequent collisions to structures. Nodular ulcerated lesions on the plantar surface of toes (toes I and III are illustrated in Figure 1) and yellowish enlarged fatty liver were noted at necropsy. At histopathology, steatosis and liver and kidney congestions were observed. Staphylococcus aureus coagulase positive was isolated from the synovial fluid and from the liver. $\boldsymbol{S}$. aureus is a common etiology for arthritis, osteomyelitis and septicemia in avian species. The cement pavement was rough and abrasive and similar to the type associated to skin abrasions in previous cases of bumblefoot in flamingos (unpublished data) of another aviary. The isolation of $\boldsymbol{S}$. aureus in pure culture from the synovial fluid and liver were considered for establishing an infectious etiology for the arthritis and for the septicemic disease, respectively. The initial foot pad lesion was considered an entry for an ascending infection which might have subsequently become systemic. Pododermatitis, arthritis and systemic disease were previously reported in domestic (CLARK et al., 2002) and wild turkeys (DAVIDSON et al., 1985)

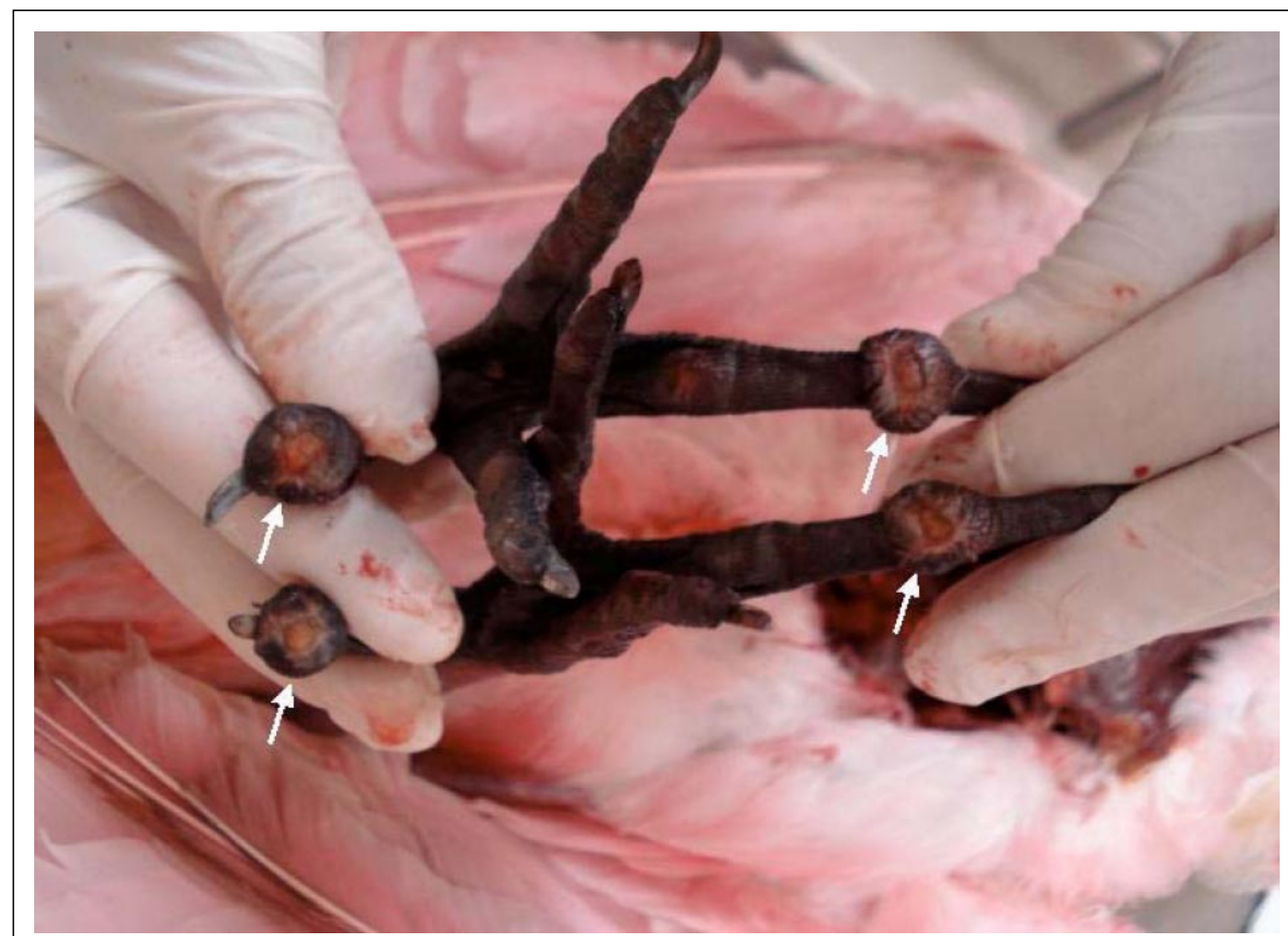

Figure 1 - Podal lesions in roseate spoonbill (Platalea ajaja). The plantar lesions in fingers I and III of a roseate spoonbill are shown and each lesion presents an ulcer. The skin opening lesions are visible (arrows).

Ciência Rural, v.39, n.6, set, 2009. 
and hawks (MÜLLER et al., 2000). The antibiotic sensitivity test revealed $\boldsymbol{S}$. aureus growth-inhibition by all (cefalotin, enrofloxacin, erithromycin, florfenicol, gentamycin, neomycin, novobiocin, oxacyllin, penicillin, sulfa + trimethoprim and tetracycline) except penicillin. Although all other bird species sharing the pen presented foot pad lesions, except for the spoonbill and the black swan, it did not evolve to a debilitating or fatal disease.

The abrasive cement rim around the pond was considered a predisposing condition for the foot pad lesions. The modifications suggested for reducing foot pad skin wear would involve either removing the cement pavement or setting a scalloping stepping margin. Some aspects of the outbreak may be of relevance, namely the involvement of multiple species and the possible higher susceptibility of the roseate spoonbill and the black swan to this $\boldsymbol{S}$. aureus isolate, as compared to the wood and white-faced ducks and the scarlet ibis.

\section{ACKNOWLEDGEMENTS}

The authors are indebted to Conselho Nacional de Desenvolvimento Científico e Tecnológico (CNPq), Fundação de Apoio à Pesquisa do Estado de Minas Gerais (FAPEMIG) and FEP/MVZ for financial support

\section{REFERENCES}

ANDREASEN, C. B. Staphylococcosis. In: H. J. BARNES, H.J. et al. (Eds.). Diseases of poultry. 9.ed. Aimes, IA: Iowa State University, 2003. p.798-804.

CLARK, S. et al. Pododermatitis in turkeys. Avian Diseases, v.46, n.4, p.1038-1044, 2002.

COOPER, J. E.; NEEDHAM, J.R. An investigation into the prevalence of $\boldsymbol{S}$. aureus on avian feet. Veterinary Record, v.28, p.172-174, 1976.

CORNELL Lab of Ornithology. All about birds. 2008. Disponível em: http://www.birds.cornell.edu/AllAboutBirds/ BirdGuide/Roseate_Spoonbill_dtl.html. Acesso em 27 fev 2009.

DAVIDSON, W. R. et al. Diseases diagnosed in wild turkeys (Meleagris gallopavo) of the southeastern United States. Journal of Wildlife Diseases, v.21, n.4, p.386-390, 1985.

MÜLLER, M. G. et al. Bumblefoot and lack of exercise among wild and captive-bred falcons tested in the United Arab Emirates. Avian Diseases, v.44, p.676-680, 2000. 